\title{
THE NEED FOR NEW MICROBIOLOGICAL WATER QUALITY CRITERIA
}

The microbiological criteria for water quality were established such as to protect consumers from possible microbiological pollution which may cause public health hazards. Therefore, the bacteriological standards for drinking water are based mainly on bacterial indicators. Another problem of prime concern to public health is the presence of antibiotic-resistant bacteria in drinking water.

Antibiotic-resistant bacteria were found among standard plate count population of chlorinated drinking water from two districts in Cairo. Most strains (89\%) appeared to be ampicillin-resistant. Those were followed by sulfaguanidine-resistant $(78 \%)$ and streptomycin-resistant $(57 \%)$ ones. The majority of the strains tested were resistant to two or more antibiotics (multiple antibiotic-resistant, MAR) which represent 62.4 to $98 \%$ of the total isolates. Identification of 363 MAR strains revealed that Gram-positive rods were dominant. Gram-negative fermentative rods, Gram-positive cocci and Gram-negative nonfermentative rods represent the second, third and fourth group of the identified MAR phenotypes.

A total of 101 isolates (non-fecal coliform) from underground water pumped from three water plants in Cairo were classified in genera or groups according to their morphological, cultural and physiological characters and their resistance to four commonly used antibiotics (chloramphenicol, tetracyclin, neomycin, penicillin) and one chemotherapeutic agent (sulfanilamide pyrimidine) was tested. Results showed that 77 and 64 isolates have acquired resistance to penicillin and sulfanilamide pyrimidine, respectively; 32 isolates were resistant to tetracyclin. Only 18 and 8 isolates were resistant to chloramphenicol and neomycin, respectively. It was also found that 19 isolates belonging to 6 genera or groups were sensitive to all compounds tested.

Therefore, any source of antibiotic-resistant bacteria must be investigated carefully and use of the data on MAR bacteria should be made in future deliberations about water quality and in regulation over the quality of effluents discharged.

\section{INTRODUCTION}

The microbiological criteria for water quality were established such as to protect consumers from possible microbial pollution which may cause public health hazards. Therefore, the bacteriological standards for drinking water are based mainly on total coliform, fecal coliform, fecal streptococci and heterotrophic bacteria densities [12].

*Water Pollution Control Laboratory, National Research Center, Dokki, Cairo, Egypt. 
Another problem of prime concern to public health is the presence of antibiotic-resistant bacteria in drinking water. In recent years, the usage of low concentrations of antibiotics in animal feed to promote growth, and the geater emphasis by the medical professions on antibiotic therapy for treating a wide spectrum of bacteria polluting the environment, is frequently considered. Previous studies proved that inadequately treated sewage and wastes are the main sources of antibiotic-resistant bacteria in the environment. For example, the antibiotic resistance of 582 different bacterial isolates to 5 antibiotics was surveyed [18]. The author found that 57 isolates were drug-resistant and classified as Gram-negative bacteria. The strong drug-resistance of some isolates is suggestive of resistance factor ( $\mathrm{R}$ factor) responsible for moderated resistance, none of the 57 drug-resistant isolates transmitted resistance to the sensitive recipients. The detection of antibiotic-resistant bacteria in water resources was studied by many investigators. Some of them [11] associated the isolation of antibiotic-resistant bacteria in streams with the degree of water pollution. It was reported [7] that the incidence of antibiotic-resistance among total and fecal coliforms reached more than $40 \%$ in potable water samples from the springs and wells tested, while it was increased to $60 \%$ in stream and seawater samples. The discovery that resistance characteristics can be transferred via $\mathrm{R}$ factor (resistance plasmid) to sensitive recipient cells has emphasized the magnitude of the problem [20].

The present investigation was undertaken to assess the number of antibiotic-resistant bacteria present in treated drinking water as well as in groundwater (untreated drinking water) in Cairo.

\section{MATERIALS AND METHODS}

\subsection{SAMPLING OF TREATED SURFACE WATER AND MIXTURE OF TREATED AND GROUND WATERS}

Drinking tap water samples were collected over a period of several months (September 1983 to March 1984) from two districts in Cairo, namely El-Dokki and Nasr-City. El-Dokki district receives its water from the El-Giza water treatment plant which is supplied with water from the River Nile. Raw water is flocculated and coagulated with alum, filtered through sand filters, chlorinated, collected in storage tank, chlorinated again and pumped into the distribution system, Nasr-City district receives its water from the Mostrod water treatment plant which is supplied with a mixture of raw water from the Ismailia Canal and underground waters.

The water from the Ismailia Canal is treated in the same way as the water from the River Nile in El-Giza water treatment plant.

Two water samples were collected in $1 \mathrm{dm}^{3}$ sterile plass bottles, each containing $1 \mathrm{~cm}^{3}$ of $10 \%$ sodium thiosulfate. Samples were examined within $2 \mathrm{~h}$ of collection.

\subsubsection{STANDARD PLATE COUNT (SPC) BACTERIA}

Bacteria were counted as follows: suitable volume of a sample (50 and/or $100 \mathrm{~cm}^{3}$ ) was passed through Sartorious membrane filters ( $\mathrm{GMbH}$, Gottingen, Germany) of $0.45 \mu \mathrm{m}$ 
pore size. Thereafter the filters were placed on $\mathrm{m}$-SPC agar [22] and incubated for $48 \mathrm{~h}$ at $35^{\circ} \mathrm{C}$. Bacterial colonies were counted using a binocularscope at $15 \mathrm{x}$ magnification.

\subsubsection{ANTIBIOTIC-RESISTANCE DETERMINATION}

Nutrient agar (Difco) was used as a basal medium to determine antibiotic-resistance of the strains tested. Antibiotic-containing media were prepared by adding sterilized antibiotic solution to melted and tempered $\left(48-50^{\circ} \mathrm{C}\right)$ nutrient agar. The antibiotics used and their final concentrations per $\mathrm{cm}^{3}$ of the medium were as follows: ampicillin $(15 \mu \mathrm{g})$, tetracycline hydrochloride $(15 \mu \mathrm{g})$, chloramphenicol $(25 \mu \mathrm{g})$, streptomycin sulfate $(15 \mu \mathrm{g})$ and sulfaguanidine $(350 \mu \mathrm{g})$.

To test their resistances to antibiotics, the colonies (50-100) were randomly selected from the m-SPC filters and inoculated onto $\mathrm{m}$-SPC agar plates. After $48 \mathrm{~h}$ incubation at $35^{\circ} \mathrm{C}$, the master plate colonies were replicated onto the medium containing antibiotics. Five antibiotic plates and one control plate containing no antibiotic were inoculated consecutively. Plates were incubated at $35^{\circ} \mathrm{C}$ for $24 \mathrm{~h}$ and antibiotic resistances of bacteria were determined. An organism was considered as resistant to an antibiotic if it grew on the antibiotic plate as well as on the control plate. Each sign of growth inhibition was scored as bacterial sensitivity to that antibiotic.

\subsubsection{IDENTIFICATION OF MULTIPLE ANTIBIOTIC-RESISTANT (MAR) STRAINS}

MAR strains to be identified were picked from the control plates and inoculated into nutrient broth (Difco). After incubation for $24 \mathrm{~h}$ at $35^{\circ} \mathrm{C}$, a loopful of each culture was streaked onto nutrient agar (Difco). A single colony from each plate was used for identification. All strains were classified into genera or groups by determining colony and cell morphology, Gram-staining, catalase and oxidase reactions, motility, urease, indole and glucose fermentation or oxidation using schema of BUCHANAN and GIBBONS [6], LENNETTE at al. [15] and LeCHEVALIER et al. [14], respectively.

\subsection{EXPERIMENTAL FOR UNDERGROUND WATER STUDY}

Underground water samples were taken from 13 wells in three water treatment plants (Mostrod, El-Marg and El-Maadi) in Greater Cairo. Samples were aseptically collected from wells in sterile $1 \mathrm{dm}^{3}$ bottles and analysed within $4 \mathrm{~h}$. Aliquots of $10 \mathrm{~cm}^{3}$ were inoculated in test tubes containing $10 \mathrm{~cm}^{3}$ of MacConkey broth medium (double strength). Acid and gas produced after $48 \mathrm{~h}$ at $37^{\circ} \mathrm{C}$ proved that coliforms were presented in test tubes. All tubes with coliforms were then inoculated in EC broth [9] and incubated in a circulating water bath for $24 \mathrm{~h}$ at $44.5 \pm 0.1^{\circ} \mathrm{C}$. Bacteria other than fecal coliforms, which could produce acid and gas at $37^{\circ} \mathrm{C}$, but not at $44.5^{\circ} \mathrm{C}$, were isolated from the inoculated MacConkey tubes. Bacterial strains representing different wells were isolated by streaking on Eosin Methylene Blue agar (EMB) and purified [16]. The strains were classified into genera or groups [14].

Resistance of bacteria to chloramphenicol, tetracycline hydrochloride, neomycin sulfate, penicillin G-sodium salt and 2-sulfanilamide pyrimidine was studied. Nutrient agar medium was enriched with the antibiotic tested to give final concentration of $50 \mu \mathrm{g}$ of 
international unit $/ \mathrm{cm}^{3}$. Five plates with different antibiotics or the chemotherapeutic sulfadiazine were streaked in parallel raws with test organisms and incubated at $37^{\circ} \mathrm{C}$ for 48 h. Antibiotic resistance was determined by comparing growth on medium enriched with antibiotics with the corresponding control devoid of antibiotics.

\section{RESULTS}

Drinking water samples collected from two districts in Cairo were tested for presence of antibiotic-resistant bacteria. The antibiotics used for this investigation were selected to include those most commonly applied in therapy. It is emphasized that the antibiotic concentrations used for screening the resistant bacteria are the levels accepted as constituting clinical resistance [19].

Ta b le 1

Percentages of antibiotic-resistant bacteria among SPC isolates from drinking samples

\begin{tabular}{|c|c|c|c|c|c|c|c|}
\hline \multirow{2}{*}{$\begin{array}{c}\text { Source and } \\
\text { date of sampling }\end{array}$} & \multirow[t]{2}{*}{$\mathrm{SPC} / \mathrm{cm}^{3}$} & \multirow{2}{*}{$\begin{array}{c}\text { No. of strains } \\
\text { examined }\end{array}$} & \multicolumn{5}{|c|}{ Percentage of isolates resistant to } \\
\hline & & & Amp. ${ }^{1}$ & Tet. $^{2}$ & $\mathrm{Cm} .^{3}$ & Str. ${ }^{4}$ & Sug. ${ }^{5}$ \\
\hline \multicolumn{8}{|l|}{ El-Dokki } \\
\hline September 1983 & 38 & 163 & 57.4 & 9.5 & 16.7 & 20.9 & 54.4 \\
\hline October 1983 & 2 & 100 & 84 & 56 & 25 & 31 & 35 \\
\hline December 1983 & 2 & 100 & 94 & 74 & 6 & 12 & 75 \\
\hline January 1984 & 0.6 & 100 & 89 & 0 & 0 & 2 & 74 \\
\hline March 1984 & 0.4 & 100 & 96 & 27 & 9 & 12 & 100 \\
\hline Total & & 563 & 84 & 33.3 & 11.3 & 15.5 & 67.6 \\
\hline \multicolumn{8}{|l|}{ Nasr-City } \\
\hline November 1983 & 1 & 50 & 80 & 78 & 12 & 74 & 80 \\
\hline December 1983 & 2 & 100 & 97 & 86 & 15 & 16 & 76 \\
\hline January 1984 & 1 & 97 & 84.5 & 0 & 0 & 94.8 & 56.7 \\
\hline February 1984 & 0.2 & 50 & 90 & 8 & 4 & 68 & 92 \\
\hline March 1984 & 3.4 & 100 & 97 & 6 & 1 & 32 & 86 \\
\hline Total & & 397 & 89.7 & 35.6 & 6.4 & 56.9 & 78.1 \\
\hline
\end{tabular}

The resistances to the antibiotics tested of 563 isolates from El-Dokki were arranged in the following ascending order: ampicillin $>$ sulfaguanidine $>$ tetracycline $>$ streptomycin $>$ chloramphenicol. A quite similar pattern was obtained for 397 isolates from NasrCity. It was: ampicillin $>$ sulfaguanidine $>$ streptomycin $>$ tetracycline $>$ chloramphenicol (table 1). These observations may reflect very well the usage patterns of 
these antibiotics [21]. It is interesting to note that in January the bacterial resistances to tetracycline and chloramphenicol were $0.0 \%$ in the samples from both districts (table 1). Such a trend may be related to the low SPC population and/or to the limited diversity of species during the cold winter period [14].

Table 2

Percentages of bacterial isolates carrying different numbers of resistance determinants $(R)$ isolated from drinking water samples

\begin{tabular}{|c|c|c|c|c|c|c|}
\hline \multirow[t]{2}{*}{$\begin{array}{c}\text { Source and } \\
\text { sampling date }\end{array}$} & \multicolumn{5}{|c|}{$\begin{array}{c}\text { Percentage of strains carrying different numbers } \\
\text { of } \mathrm{R} \text { determinants* }\end{array}$} & \multirow[t]{2}{*}{$\begin{array}{r}\text { Percenta } \\
\text { of isolat }\end{array}$} \\
\hline & $1 \mathrm{R}$ & $2 \mathrm{R}$ & $3 R$ & $4 \mathrm{R}$ & $5 R$ & \\
\hline \multicolumn{7}{|l|}{ El-Dokki } \\
\hline September 1983 & 25.7 & 37.4 & 20.8 & 3.0 & 1.2 & 62.5 \\
\hline October 1983 & 10.0 & 34.0 & 35.0 & 18.0 & 1.0 & 88.0 \\
\hline December 1983 & 12.0 & 28.0 & 45.0 & 12.0 & 2.0 & 87.0 \\
\hline January 1984 & 18.0 & 75.0 & 2.0 & 0 & 0 & 77.0 \\
\hline March 1984 & 2.0 & 58.0 & 32.0 & 8.0 & 0 & 98.0 \\
\hline Sub-total isolates & 14.9 & 45.4 & 26.2 & 7.6 & 0.8 & 80.0 \\
\hline \multicolumn{7}{|l|}{ Nasr-City } \\
\hline November 1983 & 8.0 & 6.0 & 10.0 & 66.0 & 2.0 & 84.0 \\
\hline December 1983 & 2.0 & 28.0 & 53.0 & 16.0 & 0 & 97.0 \\
\hline January 1984 & 11.3 & 38.1 & 49.4 & 0 & 0 & 89.0 \\
\hline February 1984 & 0 & 34.0 & 58.0 & 4.0 & 0 & 96.0 \\
\hline March 1984 & 5.0 & 68.0 & 23.0 & 3.0 & 0 & 94.0 \\
\hline Sub-total isolates & 5.5 & 38.5 & 39.7 & 13.6 & 0.2 & 92.0 \\
\hline$\%$ of total isolates & 11.0 & 42.6 & 31.8 & 10.1 & 0.006 & 85 \\
\hline
\end{tabular}

*Percentages are related to the number of isolates tested (see table 1).

Of the total screened antibiotic-resistant bacteria (960 strains isolated from water samples of both districts), the percentage of singly, doubly, triply, quadruply and quintuply resistant strains were: $11.0,42.6,31.8,10.1$ and 0.006 , respectively. Thus, approximately $85 \%$ of these strains were considered as MAR (table 2).From comparison of resistance patterns it was evident that the percentage of the antibiotic-resistant strains carrying different numbers of resistant determinants $(R)$ varied in the water samples from each district as well as between the samples of both districts (table 2). The percentage of strains carrying $1 \mathrm{R}, 2 \mathrm{R}$, and $5 \mathrm{R}$ in the water samples from El-Dokki district were higher than those characteristic of Nasr-City. The percentages of MAR strains isolated from El-Dokki and Nasr-City water samples were $80 \%$ and $92 \%$, respectively (table 2). 
Ta b le 3

Identities of some MAR strains isolated from drinking water samples

\begin{tabular}{|c|c|c|c|c|}
\hline \multirow[t]{2}{*}{ Identity } & \multicolumn{2}{|c|}{ El-Dokki } & \multicolumn{2}{|c|}{ Nasr-City } \\
\hline & $\begin{array}{l}\text { No. of } \\
\text { isolates }\end{array}$ & $\begin{array}{c}\% \text { of } \\
\text { total MAR }\end{array}$ & $\begin{array}{l}\text { No. of } \\
\text { isolates }\end{array}$ & $\begin{array}{c}\% \text { of } \\
\text { total MAR }\end{array}$ \\
\hline 1.Gram-negative, nonfermentative rods & & 2.5 & & 1.2 \\
\hline Acinetobacter spp. & 1 & & 0 & \\
\hline Alcaligenes spp. & 3 & & 0 & \\
\hline Moraxella spp. & 1 & & 0 & \\
\hline Flavobacterium spp. & 0 & & 2 & \\
\hline 2. Gram-negative, fermentative rods & & 3.5 & & 13 \\
\hline Aeromonas spp. & 1 & & 12 & \\
\hline Citrobacter freundii & 1 & & 3 & \\
\hline Enterobacter aerogenes/cloacae & 4 & & 6 & \\
\hline Hafnia & 1 & & 0 & \\
\hline 3. Gram-positive cocci & & 1.0 & & 8.6 \\
\hline Micrococcus spp. & 2 & & 14 & \\
\hline 4. Gram-positive rods & & 93 & & 77.2 \\
\hline Bacillus spp. & 172 & & 125 & \\
\hline Corynebacterium & 15 & & 0 & \\
\hline Total number of identified isolates & 201 & & 162 & \\
\hline
\end{tabular}

The identities of some isolated MAR phenotypes (363 strains) are presented in table 3. Four major groups were identified according to Gram-staining, fermentative metabolism and cell morphology. Gram-positive rods constituted the largest portion of MAR phenotypes and represented $93 \%$ and $77.2 \%$ of the total identified strains isolated from El-Dokki and Nasr-City water samples, respectively. Gram-negative fermentative rods represented the second largest group, while the Gram-positive cocci and Gram-negative nonfermentative rods constituted the third and fourth groups of identified MAR strains.

A total of 101 isolates representing flora from 13 wells in three water works were purified and classified into genera or groups. The majority of isolates were found to belong to Gram-negative rods (47.52\%), while only 8 strains $(8.91 \%)$ were referring to Gram-positive rods. The classified strains were tested for their resistances to four antibiotics (chloramphenicol, tetracycline, neomycin and penicillin) as well as sulfanilamide pyrimidine. According to their resistances, bacterial isolates were divided into 3 groups (resistant to one antibiotic, resistant to more than one antibiotic and nonresistant strains). 
Ta ble 4

Antibiotic-resistance patterns for strains isolated from well water

\begin{tabular}{|c|c|c|c|c|c|c|c|}
\hline \multirow[t]{2}{*}{ Location } & \multicolumn{5}{|c|}{ Antibiotic resistance* } & \multirow{2}{*}{$\begin{array}{l}\text { No. of } \\
\text { isolates }\end{array}$} & \multirow{2}{*}{$\begin{array}{c}\% \text { of strains isolated } \\
\text { from well }\end{array}$} \\
\hline & $\mathrm{Cm}^{1}$ & Tet. $^{2}$ & $\mathrm{Neo}^{3}$ & Pen. ${ }^{4}$ & Sulf. $^{5}$ & & \\
\hline \multirow[t]{7}{*}{ Mostrod } & - & - & - & - & - & 7 & 31.8 \\
\hline & - & - & - & + & - & 3 & 13.6 \\
\hline & - & - & - & - & + & 3 & 13.6 \\
\hline & + & - & - & + & - & 1 & 4.5 \\
\hline & - & + & - & + & + & 3 & 13.6 \\
\hline & + & + & - & + & + & 3 & 13.6 \\
\hline & + & + & + & + & + & 2 & 9.1 \\
\hline \multirow[t]{10}{*}{ El-Maadi } & - & - & - & - & - & 4 & 6.3 \\
\hline & - & - & - & + & - & 11 & 17.4 \\
\hline & - & + & - & - & - & 1 & 1.6 \\
\hline & - & - & - & + & + & 29 & 46.0 \\
\hline & + & - & - & + & + & 3 & 4.7 \\
\hline & - & + & - & + & + & 4 & 6.3 \\
\hline & + & + & - & - & + & 1 & 1.6 \\
\hline & - & + & + & + & + & 4 & 6.3 \\
\hline & + & + & - & + & + & 4 & 6.3 \\
\hline & + & + & + & + & + & 2 & 3.2 \\
\hline \multirow[t]{4}{*}{ El-Marg } & - & - & - & - & - & 8 & 50.0 \\
\hline & - & + & - & + & - & 2 & 12.5 \\
\hline & - & + & - & + & + & 4 & 25.0 \\
\hline & + & + & - & + & + & 2 & 12.5 \\
\hline
\end{tabular}

Results recorded in table 4 summarize the antibiotic resistance of the isolated strains to the individual compound. It becomes evident that the majority of the isolated strains (63\%) are characterized by multiple resistance ability towards two or more compounds $(2 \mathrm{R}, 3 \mathrm{R}, 4 \mathrm{R}$ and $5 R$ ) (table 4). It is interesting to note that within a specific genus, some species (or strains) may be sensitive to the aforementioned antibiotics, while others belonging to the same genus can be resistant to one or more of these compounds. Most strains(76.23\%) appeared to be penicillin resistant. These were followed by strains resistant to sulfanilamide pyrimidine $(63.36 \%)$, tetracycline (31.68\%), chloramphenicol (17.82\%) and neomycin (7.92\%). 
Table 5

Antibiotic-resistance pattern for some strains isolated from underground water

\begin{tabular}{|c|c|c|c|c|c|c|c|}
\hline \multicolumn{5}{|c|}{ Antibiotic resistance } & \multirow{2}{*}{$\begin{array}{c}\mathbf{R} \\
\text { Det. }\end{array}$} & \multirow{2}{*}{$\begin{array}{l}\text { Number of } \\
\text { isolates }\end{array}$} & \multirow[t]{2}{*}{ Genera or groups } \\
\hline $\mathrm{Cm}^{1}$ & Tet. $^{2}$ & $\mathrm{Neo}^{3}$ & Pen. ${ }^{4}$ & Sulf. 5 & & & \\
\hline - & - & - & + & - & 1 & 14 & $\begin{array}{l}\text { Acinitobacter(1), Aeromonas(1), } \\
\text { Flavobacterium(1), Bacillus(2), } \\
\text { Moraxella(2), Pseudomonas(7) }\end{array}$ \\
\hline - & - & - & - & + & 1 & 3 & $\begin{array}{l}\text { Bacillus(1), Micrococcus(1), } \\
\text { Moraxella like group M (1) }\end{array}$ \\
\hline- & + & - & - & - & 1 & 1 & Micrococcus(1) \\
\hline - & - & - & - & - & $\mathbf{0}$ & 19 & $\begin{array}{l}\text { Aerobacter(2), Bacillus(2), } \\
\text { Enterobacteriaceae(1), Micrococcus(8), } \\
\text { Moraxella(2), Pseudomonas(4) }\end{array}$ \\
\hline
\end{tabular}

Table 6

Identities of MAR strains isolated from well water

\begin{tabular}{|c|c|c|c|c|c|c|}
\hline \multirow[t]{2}{*}{ Identity } & \multicolumn{2}{|c|}{ Mostrod } & \multicolumn{2}{|c|}{ El-Maadi } & \multicolumn{2}{|c|}{ El-Marg } \\
\hline & $\begin{array}{l}\text { No. of } \\
\text { isolates }\end{array}$ & $\begin{array}{l}\% \text { of } \\
\text { total } \\
\text { MAR }\end{array}$ & $\begin{array}{l}\text { No. of } \\
\text { isolates }\end{array}$ & $\begin{array}{c}\% \text { of } \\
\text { total } \\
\text { MAR }\end{array}$ & $\begin{array}{l}\text { No. of } \\
\text { isolates }\end{array}$ & $\begin{array}{l}\% \text { of } \\
\text { total } \\
\text { MAR }\end{array}$ \\
\hline Gram-negative nonfermentative rods & & 0 & & 63.8 & & 0 \\
\hline Moraxella spp. & 0 & & 10 & & 0 & \\
\hline Flavobacterium spp. & 0 & & 1 & & 0 & \\
\hline Pseudomonas/Alcaligenes & 0 & & 19 & & 0 & \\
\hline Gram-negative fermentative rods & & 33.33 & & 19.1 & & 62.5 \\
\hline Aeromonas & 2 & & 4 & & 0 & \\
\hline Enterobacteriaceae & 1 & & 5 & & 5 & \\
\hline Gram-positive cocci & & 55.55 & & 10.6 & & 37.5 \\
\hline Micococcus spp. & 1 & & 1 & & $\mathbf{0}$ & \\
\hline Staphylococci & 4 & & 4 & & 3 & \\
\hline Gram-positive rods & & 11.11 & & 6.3 & & 0 \\
\hline Bacillus spp. & 1 & & 3 & & & 0 \\
\hline Total MAR & 9 & & 47 & & 8 & \\
\hline
\end{tabular}


Results proved that 19 strains belonging to 6 genera or groups were sensitive to all the compounds tested, while the remaining isolates can be resistant to one or more of them. Only 18 isolates belonging to 7 genera and one group were resistant to one compound only, i.e. tetracycline, penicilline, or sulfanilamide pyrimidine (table 5).

The identities of the MAR phenotypes (64 strains) are presented in table 6. Four major groups were identified. Generally, Gram-negative nonfermentative rods constituted the largest portion of MAR phenotypes isolated from El-Maadi wells and represented $63.8 \%$ of the isolates. Gram-negative fermentative rods represented 33.3, 19.1 and $62.5 \%$ of the MAR isolated from Mostrod, El-Maadi and El-Marg wells, respectively (table 6). Gram-positive cocci represented 55.5, 10.6 and $31.5 \%$ of the MAR isolates from Mostrod, El-Maadi and El-Marg wells, respectively. Finally, Gram-positive rods represented 11.1 and $6.3 \%$ of the MAR isolates from Mostrod and El-Maadi,respectively.

\section{DISCUSSION}

The results of investigations clearly indicate that antibiotic-resistant bacteria are present among the populations tested. MAR strains prevailed among the isolates. Although the comparison of the percentages of resistant strains with those published by other researchers is quite difficult due to differences in type and concentrations of the antibiotics tested, our results are quite close to those reported by ARMSTRONG et al. [2]. They reported the presence of MAR isolates among SPC bacteria from drinking water of 6 communities in Oregon State, the U.S.A. The percentages reported by them ranged from 27.4 to $86.1 \%$ with an average value of $33.9 \%$. Their investigations were similar to ours, because they also stated that the majority of MAR strains were resistant to two and three antibiotics.

The drinking water samples tested have a very low SPC (table 1) and the majority of MAR organisms are nonpathogenic (table 3 ). However, the presence of strains belonging to Acinetobacter spp., Moraxella spp. and Flavobacterium spp. could present a potential hazard to patients in hospitals, clinics, nurseries and rest homes ([9] and [13]). Bacillus spp., especially sporeformers, cause decaying of food products, beverages and spoiling of cosmetics and drugs [5], [10]. Such organisms may act as opportunistic pathogens [23] or may transfer their antibiotic resistance to other pathogenic microorganisms present in the intestinal tract of the consumer.

Our investigations concerning well water prove that among the isolated bacteria the majority (63.3\%) are of multiple resistance ability towards more than one of the commonly used drugs in Egypt. Of the total screened antibiotic-resistant strains, the percentage of doubly, triply, quadruply and quintuply resistant strains were $31.68 \%, 14.85 \%, 12.87 \%$ and $3.96 \%$, respectively. It is an interesting observation that within a specific genus, some species may be sensitive to some antibiotics, while others belonging to the same genus are resistant to one or more of these substances. In this respect, ARMSTRONG et al. [3] found that among the bacterial isolates from untreated river water in Oregon State, the multiple antibiotic-resistant bacteria were found to constitute 15.8 and $18.2 \%$ compared to 57.1 and $43.5 \%$ of MAR bacteria from the chlorinated clear well water on the same sampling dates. The same authors reported that chlorination of water during the treat- 
ment process could be responsible for a selection of antibiotic-resistant bacteria in the environment.

As a consequence of the development and proliferation of antibiotic-resistant bacteria, the therapeutic value of these drugs may be impaired. In this connection, our statement that the number of SPC isolates resistant to chloramphenicol were very low (table 1) must be considered carefully, since this antibiotic is the drug of choice for Salmonella typhi infections. Therefore every source of antibiotic-resistant bacteria must be tested thoroughly, and examination of data on MAR bacteria should be taken into account in the future water quality deliberations and in regulations of the quality of effluent discharges.

The present study proves that although the strains isolated are not pathogens, the probability of acquiring the multiple antibiotic resistance by pathogens, which in turn creates hygienic problems in modern society, should be considered.

\section{REFERENCES}

[1] American Public Health Association, Standard Methods for the Examination of Water ans Wastewater, 15th ed., APHA, Washington, D.C. 1980.

[2] ARMSTRONG J.L., SHIGENO D.S., CALOMIRIS J.J., SEIDLER R.J., Antibiotic-resistant bacteria in drinking water, Appl. Environ. Microbiol., 42 (1981), 277-283.

[3] ARMSTRONG J.L., CALOMIRIS J.J., SEIDLER R.J., Selection of antibiotic-resistant standard plate count bacteria during water treatment, Appl. Environ. Microbiol., 44 (1982), 308-316.

[4] BELL J.B., MARCALE W.R., ELLIOT G.E., Incidence of $R$ factors in coliform, fecal coliform, and Salmonella populations of Red River of Canada, Appl. and Environ. Microbiol., 40 (1980), 486-491.

[5] BORGSTROM S., Principles of food science. Vol. II. Food microbiology and biochemistry, Macmillan Co., Collier Macmillan Ltd, London 1968.

[6] BUCHANAN R.E., GIBBONS N.E., Bergey's manual of determinative bacteriology, 8th ed., The Williams \& Wilkins Co., Baltimore 1974.

[7] COOKE M., LOUTIT M., MULCOCK A.P., PYLE B.H., TAYLOR M.E., TILL D.G., Definition of ternun concerning coliform bacteria and recommended methods for earlier detection, New Zealand J. Sci., 19 (1976), 215-219.

[8] CULP R.L., Disease due to "Non-pathogenic bacteria", JAWWA, 61 (1969), 157-162.

[9] Difco Mannual: Difco manual for microbiological and clinical laboratory procedures, Difco Laboratories Incorporated, 9th ed., Detroit, Michigan 1953.

[10] DUNNIGAN A.P., Microbiological control of cosmetic products (in federal regulations and practical control microbiology for disinfectants, drugs and cosmetics), Soc. for Industrial Microbiol. Spec. Publ., No. 4 (March 1969).

[11] FEARY T.W., STURTEVANT A.B., LANKFORD J., Antibiotic resistant coliforms in fresh and salt water, Arch. Environ. Health, 25 (1972), 215-220.

[12] GELDREICH E.E., Microbiology: Water, J.W.P.C.F., 54 (1982), 931-943.

[13] HERMAN L.S., HIMMELSBACุH C.K., Detection and control of hospitals sources of Flavobacteria, Hospitals, 39 (1965), 72-78.

[14] LeCHEVALLIER M.W., SEIDLER R.J., EVANS T.M., Enumeration and characterization of standard plate count bacteria in chlorinated and raw water supplies, Appl. and Environ. Microbiol., 40 (1980), 922-930.

[15] LENNETTE E.H., SPAULING E.H., TRUANT J.P., Manual of clinical microbiology, 2nd ed., American Society for Microbiology, Washington, D.C. 1974.

[16] LEVINE M., Differentiation of E. coli and A. aerogenes on a simplified eosin-methylene blue agar, J. Inflect. Dis., 23 (1918), 43-47.

[17] LINTON A.H., Antibiotics, animal and man. An appraisal of contentiots subject, 315-343, [in:] Antibiotics and antibiotics in agriculture, Woodbine M. (ed.), Butterworths, London-Boston 1977.

[18] MARE I.J., Incidence of $R$-factors among Gram-negative bacteria in drug-free human and animal communities, Nature, 220 (1968), 1046-1047. 
[19] MATSEN J.M., BARRY A.L., Susceptibility testing diffusion test procedures, p. 418, [in:] Manual of clinical microbiology, Lenette E.H., Spaulding E.H., Truant J.P. (eds.), 2nd ed., American Society for Microbiology, Washington, D.C. 1974.

[20] MITSUHASHI S., Epidemiology of $R$ factors, pp. 25-45, [in:] $R$ factor drug resistance plasmid, S. Mitsuhashi (ed.), University Park Press, Baltimore 1977.

[21] RICHMOND M.H., Some environmental consequences of the use of antibiotic: or "What goes up must come down", J. Appl. Bact., 35 (1972), 155-176.

[22] TAYLOR R.H., GELDREICH E.E., A new membrane filter procedure for bacterial counts in potable water and swimming pool samples, J. Am. Water Works Assoc., 71, 402-406.

[23] Von GRAEVENITZ A., The role of opportunistic bacteria in human disease, Annu. Rev. Microbiol., 31, 447-471.

\section{NOWE KRYTERIA MIKROBIOLOGICZNE JAKOŚCI WODY}

Mikrobiologiczne kryteria jakosci wody opracowano, aby chronic konsument 6 w przed ewentualnym mikrobiologicznym zanieczyszczeniem, mogącym stanowic zagrożenie dla zdrowia publicznego. $Z$ tego względu normy bakteriologiczne dla wody pitnej są oparte przede wszystkim na wskaźnikach bakteryjnych. Innym ważnym dla zdrowia publicznego problemem jest obecnosc w wodzie pitnej bakterii odpornych na działanie antybiotyk6w.

Badano wodę chlorowaną pochodzącą z dwóch okręgow w Kaírze. Bakterie odporne na działanie antybiotyków znajdowano w populacjach oznaczanych standardową metodą zliczania na płytce. Większoș szczepów bakteryjnych ( $89 \%$ ) była odporna na działanie sulfaguanidyny $(78 \%)$ i streptomycyny $(57 \%)$. Większosc z badanych szczepow była odporna na działanie dwóch lub więcej antybiotyków (wielokrotna odpornosé na antybiotyki MAR). Stanowią one $62,4-98 \%$ wszyst kich wyizolowanych bakterii. Identyfikacja 363 szczepów typu MAR wykazała, że dominują pałeczki Gram-dodatnie. W zidentyfikowanych fenotypach MAR w następnej kolejnosci pojawiały się fermentacyjne pałeczki Gram-ujemne, ziarenkowce Gram-dodatnie i niefermentacyjne pałeczki Gram-ujemne.

101 szczepow bakteryjnych wyizolowanych $z$ wody podziemnej pompowanej przez trzy stacje uzdatniania wody w Kairze podzielono na odpowiednie rodzaje lub grupy zgodnie $\mathrm{z}$ ich charakterystyką morfologiczną, kulturową (hodowlaną) i fizjologiczną. Zbadano odpornosé bakterii na działanie czterech powszechnie stosowanych antybiotyk6w (chloramfenikol, tetracyklina, neomycyna, penicylina) i jednego srodka chemoterapeutycznego (sulfanilamid pirymidyny). Stwierdzono, że 77 wyizolowanych szczepow bakteryjnych wykazywało odpornosc na działanie penicyliny, 64 zaś było odpornych na działanie sulfanilamidu pirymidyny. Jedynie 18 wyizolowanych szczepów bakteryjnych było odpornych na działanie chloramfenikolu, 8 zas - na działanie neomycyny. Stwierdzono również, że 19 wyizolowanych szczepów bakteryjnych było podatnych na działanie wszystkich badanych substancji.

Każde źródło bakterii odpornych na działanie antybiotyków musi być dokładnie zbadane. W rozważaniach na temat jakości wody do picia i jakości odprowadzanych scieków należy wykorzystać informacje dotyczące szczepów bakteryjnych o wielokrotnej odporności na działanie antybiotyków (MAR).

\section{НОВЫЕ МИКРОБИОЛОГИЧЕСКИЕ КРИТЕРИИ КАЧЕСТВА ВОДЫ}

Микробиологичесие критерии качества воды были разработаны с целью предохранения пользователей перед возможным микробиологическим заражением, которое может составлять опасность для здоровья общества. Из-за этого бактериологические нормы для питьевой воды опираются прежде всего на бактериальные показатели. Другой важной для общественного здоровья проблемой является присутствие в питьевой воде бактерий, устойчивых к действию антибиотиков.

Исследована хлорированная вода, происходящая из двух районов в Каире. Бактерии, устойчивые к действию антибиотиков, находили в популяциях, обозначаемых стандартным методом сосчитывания на плитке. Большинство штаммов бактерий $(89 \%)$ было устойчиво к действию ампицилина. По меньшей 
степени они были устойчивы к действию сульфагуанидина $(78 \%)$ и стрептомыцина $(57 \%)$. Большинство исследуемых штаммов было :устойчиво к действию двух или больше антибиотиков (многократная устойчивость к антибиотикам - MAP (MAR). Они составляют 62,4-98\% всех выделенных бактерий. Идентификация 363 штаммов типа МАР обнаружила, что преобладают граммположительные палочки. В идентифицированных фенотипах МАР в следующем порядке появились ферментационные грамм-отрицательные палочки, грамм-положительные микрококки и неферментационные грамм-отрицательные палочки.

101 бактериальных штаммов, выделенных из подземной воды, перекачиваемой через три установки для подготовки воды в Каире были разделены на соответствующие роды или группы согласно их морфологической, культурной и физиологической характеристикам. Исследована устойчивость бактерий к действию четырех общеприменяемых антибиотиков (хлорамфеникол, тетрациклин, неомицин, пеницилин) и одного химиотерапевтического лекарственного средства (сульфаниламид пиримидина). Было установлено, что 77 выделенных бактериальных штаммов обнаруживали устойчивость к действию пеницилина, а 64 было устойчивыми к действию сулфаниламида пиримидина. Лишь 18 выделенных бактериальных штаммов было устойчивыми к действию хлорамфеникола, а 8 - к действию неомицина. Было также установлено, что 19 бактериальных штаммов подвергались действию всех исследуемых веществ.

Каждый источник бактерий, устойчивых к действию антибиотиков, должен быть точно исследован. В рассуждениях на тему качества питьевой воды и качества отводимых сточных вод надо использовать сведения, касающиеся бактериальных штаммов многократной устойчивости к действию антибиотиков (MAP). 